\title{
НЕОІНСТИТУЦІОНАЛІЗМ ЯК ТЕОРЕТИКО-МЕТОДОЛОГІЧНА ОСНОВА СОЦІОЛОГІЧНОГО ДОСЛІДЖЕННЯ ФАРМАЦІЇ
}

\author{
С. Г. Князьков \\ Національний педагогічний університету імені М. П. Драгоманова \\ м. Київ, Україна \\ knyazkov_s_g@ukr.net
}

\begin{abstract}
В контексті інституційних реформ, що тривають сьогодні в українському суспільстві однією із найбільш контраверсійних i, водночас, необхідних є реформа інституту охорони здоров'я. Необхідність докорінного перегляду принципів функціонування цього інституту поєднується із численними ризиками, що актуалізує проблему соціологічної евалюації заходів із реформування інституту охорони здоров'я загалом і такої його складової як фармацевтика. Неоліберальний вектор реформ передбачає, серед інших заходів із оптимізації державного управління та державних видатків, поступовий перехід до моделі страхової медицини. Загрози, пов'язані із впровадженням страхової медицини, зокрема, у фармацевтичній діяльності, вимагають соціологічного моніторингу соціальних постав, потреб та побоювань основних агентів, причетних до проблемної ситуації: професійних фармацевтів, споживачі лікарських препаратів, представників компаній-виробників та фахівців із фармакоекономіки. Проблематика соціологічного супроводу фармацевтичної діяльності, і соціологічної евалюації зокрема, охоплює таке коло питань як: оцінка ефективності заходів із реформування фармацевтичної діяльності різними групами причетних агентів; бачення ризиків переходу до страхової системи медицини і фармацевтичної діяльності, зокрема; ступінь задоволеності споживачів лікарських засобів.

Варто відзначити, що у процесі фармацевтичної діяльності виникають протиріччя етичних, фінансових і професійних мотивів. Через конкуренцію на фармацевтичному ринку, його подальшу комерціалізацію посилюється фінансово-господарська, а не медико-соціальна складова фармацевтичної діяльності, що загострює моральні ризики, пов'язані із цією сферою діяльності. Посилюється ризик недобросовісної поведінки фармацевтів і, навіть, виробників лікарських препаратів; гострою залишається проблема самолікування, наявності на ринку фальсифікованих лікарських препаратів, асиметричної інформації щодо лікарських препаратів та їхнього неоптимального вибору споживачами (англ. - adverse selection) та ін. Це, у свою чергу, актуалізує соціологічну перспективу досліджень фармацевтичної діяльності, оскільки звертає увагу на функціонування соціального інституту професійноётики фармацевтів, виробників лікарських препаратів та фахівців із фармекономіки.

Ключові слова: неоінституціоналізм, фармація, евалюація.
\end{abstract}

(C) Князьков С. Г., 2017 
Сьогодні у контексті реформування системи охорони здоров'я України актуалізується потреба моніторингу та оцінки ефективності фунціонування нових інституційних форм надання медичних послуг та сприйняття цих інновацій населенням. Загалом у соціології медицини від початку ії конституювання в середині XX століття сформувалися чотири підходи: функціоналістський, конфліктний, інтеракціоністський та конструктивістський. Ці підходи, хоч і дозволили значно розширити корпус наукових знань щодо проблематики здоров'я та медицини, дуже малою мірою фокусувалися на спеціалізованих формах медичної діяльності, таких як фармація. В науковій, соціологічній зокрема, літературі на сьогодні тема оцінки фармацевтичного сектору у вимірі ефективності та у контексті сучасних трансформацій інститутут медицини висвітлена дуже фрагментарно, а існуючі дослідження, в основному, аналізують фармацевтичний сектор в організаційно-управлінському та економічному вимірах (йдеться, наприклад, про компаративний аналіз запланованих та досягнутих індикаторів діяльності) [1]. Водночас, досить численними є дослідження, у яких фармацевтична діяльність досліджується із застосуванням соціологічних методів збору та опрацювання інформації. Відповідно, констатуємо прогалину у соціологічному знанні, яка полягає у недотеоретизованості проблематики фармації як комплексного суспільного, економічного та медичного институту, відсутності соціологічної методології ії практичноорієнтованого вивчення, зокрема у інституційному та соціокультурному вимірах.

Дослідження проблематики медицини та здоров'я у соціології реалізувалися з різних теоретико-методологічних позицій. Значним $є$ корпус праць такого спрямування, виконаних із позицій інтерпретативної соціологічної парадигми та таких, що спираються на теорії дискурс-аналізу, конструкціонізму, феноменології, етнометодології та ін. Втім, для цілей нашого дослідження, очевидно, більш адекватним є опертя на ті соціологічні підходи, які дозволяють розкрити особливості інституту фармації із фіксацією обєктивних показників іiі ефективності та із потенційними управлінськими проекціями.

Найбільш оптимальним вибором соціологічної методології евалюації фармацевтичного сектору, на нашу думку, є методологія неоінституціоналізму. Вважаємо, що застосування методології неоінституціоналізму має потенціал до заповнення подібної прогалини у соціологічному вивченні фармації в сучасному українському суспільстві, зокрема у контексті становлення страхової медицини. Неоінституціоналізм сформувався у середині минулого століття у межах економічної науки та отримав визнання у 80-90-х рр. ХХ століття. Фундаментальною ознакою неоінституціоналізму $\epsilon$ принцип інститутоцентризму, згідно з яким дослідження жодної проблеми неможливе без урахування конкретної інституціональної форми життя. Неоінституціоналізм поєднує організаційно-управлінську, економічну та соціокультурну перспективу та використовується у дослідженні організаційної поведінки людини у найрізноманітніших сферах, але завжди із спрямуванням на оптимізацію організаційного середовища , підвищення інституційної ефективності. Разом з тим, тематичне охоплення цього напряму теоретизацій є навіть ширшим, оскільки включає аналіз людської поведінки в контексті сучасних інститутів ринку, культури, політики.

Як зазначено вище, центральною ознакою неоінституціоналізму є принцип значимості інститутів або інститутоцентризм, звідци відповідне широке визначення поняття 
«соціальний інститут». Інститути представляють собою регуляторні, нормативні та культурно-когнітивні рамки, сукупність яких забезпечує стабільність та осмисленість соціального життя [25].

У ключі неоінституціоналізму ми у межах цього дослідження розуміємо фармацію як соціальний інститут, який актуалізується у певному організаційному полі. Р. Скота зазначає, що використання поняття «організаційне поле» має на меті підкреслення наступних важливих аспектів: 1) важливість організацій для соціальних акторів; 2) роль політичних процесів (як загальносоцієтальних так і специфічних для цього поля) для підтримки і раціоналізації систем виробництва і споживання; 3) вплив культурнокогнітивних і нормативних факторів, які формують світогляд, інтереси і дії акторів; 4) способи організації діяльності у відносно відосіблених кластерах чіткими межами. Поняття поля вказує також на сукупності організацій, які поділяють спільну систему значень і взаємодіють між собою з більшою інтенсивністю, аніж з агентами поза межами поля. Елементами поля є індивідуальні та колективні соціальні актори, системи обміну, різні типи організацій та структури управління [24].

Два важливих поняття із теорії неоінституціоналізмуоповнюють теоретичне моделювання фармації як соціального інституту. Це інституціональна логіка та системи управління. Інституціональна логіка це система ідей і переконань, які формують мотивацію і цілеспрямовану поведінку учасників поля. Зміни ідей породжують зміни організаційного поля. Як зазначає Р. Скот: «Часом причина змін є ендогенною, тобто коріниться в самому оргіназаційному полі; в інших випадках вплив на поле здійснюється ззовні, виникаючи за його межами, але після цього проникаючи в організаційне поле і змінюючи його риси. Такого роду зміни можуть бути викликані, наприклад, соцієтальними потрясіннями (економічною депресією, війною), зміною політичних режимів та ідеологій або ж проведенням масштабних реформ» [6, с. 30]. Стосовно поточного етапу найістотнішими змінами інституціональної логіки, що мають потенціал грунтовної трансформації інституту фармації в Україні є впровадження державного солідарного медичного страхування. Розглядаючи поняття систем управління Р. Скот здійснює ретроспективний аналіз трьох етапів функціонування системи охорони здоров'я в США. Це етап домінування професіоналів (1920-1964рр.), етап державного втручання (1965-1982 рр.) та етап ринкових механізмів та контролю менеджерів (з 1983 р. дотепер). Кожному з наведених етапів відповідає релевантна система управління.

Понятійний апарат неоінституціоналізму має значне евристичне значення у дослідженні інституту фармації. Так, наприклад, йдеться про модель прийняття рішень в ситуації неповноти інформації та браку довіри, яка отримала назву «дилема в'язнів». Із використанням цієї моделі може бути проінтерпретована практика неоптимального вибору лікарських препаратів споживачами (англ. - adverse selection). Виходячи 3 організаційної перспективи взаємодії акторів, неоінституціональна теорія на перший план висуває трансакційні витрати. Вказане поняття наголошує на тому, що на усіх рівнях - інституційному, організаційному, індивідуальному - взаємодія між агентами супроводжується неминучими витратами ресурсів (грошей, часу, праці тощо) для планування, адаптації та контролю за виконанням узятих індивідами зобов'язань. Відповідно, ефективність впровадження нової інституційної логіки та систем управління прямо 
повязана із розміром трансакційних витрат дотичних акторів. Відповідно, операціоналізація ефективності фармацевтичного сектору може бути реалізована із акцентом саме на трансакційних витратах задіяних агентів у структурному, процесуальному та результативному вимірах. Так, якщо йдеться про структурний вимір то операціоналізація ефективності фармацевтичного сектору у неоінституціональній перспективі може включати задіяні матеріально-технічні, кадрові, фінансові та інтелектуальні ресурси. Процесуальний вимір акцентуватиме на процедурах призначення, закупівлі, забезпечення якості лікарських препаратів та ін. Результуючий вимір ефективності фармацевтичного сектору може операціоналізуватися через індикатори покращення якості життя пацієнтів, зникнення симптомів захворювання, впровадження в клінічну практику новітніх розробок, ефективності виявлення препаратів невідповідної якості, вартості лікарських засобів для лікування пріортетніх для громадського здоров'я захворювань, їх безперебійної наявності у медичних закладах та роздрібних аптеках та ін.

3 перспективи соціальних ролей названих акторів, окреслюються відмінності у мотивації поведінки та потенційні проблемні аспекти функціювання фармацевтичного сектора. Так, для лікаря найголовнішим $є$ визнання його професіоналізму, достатнє фінансування та комфортні умови праці [2]; для фармацевтичного пацівника - підвищення соціального статусу та престижу аптечного закладу, збільшення числа покупців лікарських препаратів та їхня довготермінова лояльність до аптеки (у приватному сегменті) [4]; для пацієнта - швидке досягнення позитивного результату терапії з найменшими фінансовими витратами [20].

Наступне важливе поняття в рамках неоінституціоналізму, яке може залучатися до теоретичного моделювання ефективності фармацевтичного сектору та іїі соціологічної евалюації це поняття «інституційна пастка». Автор цього поняття, про яку В. Полтерович говорить як про «неефективну стійку норму (неефективний інститут), що самопідтримується» [5, с. 6]. Результатом появи інституційних пасток постає формування інституційного конфлікту між чинною та новою інституційною логікою. Поняття «трансакційних витрат», «інституційних пасток», «подвійної інституціоналізації» та ін. - становлять насичений теоретико-методологічний інструментарій неоінституціоналізму, який дозволяє здійснити системне моделювання функціонування фармацевтичного сектору.

Завершуючи обгрунтування доцільності використання саме неоінституціональної теоретико-методологічної «рамки», зацитуємо українську дослідницю С. А. Щудло, яка вважає, що перевагою неоінституціонального аналізу є можливість його застосування на декількох рівнях - інституційному, організаційному та індивідуальному, що дає змогу відповісти на такі запитання: які закономірності розвитку, вибору та зміни соціальних інститутів; яким чином вибираються ті чи інші організаційні форми залежно від характеру інституційного середовища; які особливості поведінки соціальних агентів у межах різних організацій [8].

Цінність неоінституціоналізму як теоретико-методологічної основи дослідження зумовлюється і тим, що цей напрям моделює механізм інституційних змін: «допоки трансакційні витрати залишаються прийнятними для акторів, принципових змін соціального інституту не відбувається, а зі суттєвим зростанням витрат, які перевищують 
очікувані результати взаємодії, настає час змін, на зміну старим правилам приходять нові, які мінімізують витрати» [3, с.12].

Розглянемо приклади інституційних пасток, що виникають в фармацевтичному секторі системи охорони здоров'я. Спільним для усіх розглягнутих нижче інституційних пасток $є$ те, що в усіх випадках йдеться про розгортання дилеми соціального та економічного. Йдеться про нетотожність соціальної мети фармацевтичної діяльності та принципу максимізації прибутків, який є зобовязуючим для усіх комерційних організацій. Функціонування ринку лікарських засобів, на відміну від багатьох інших спеціалізованих форм ринку, слугує не лише приватним але й суспільним цілям. Потенційний конфлікт між спрямованістю на захист здоров'я населення і прагненням максимізації прибутку може мати місце в ситуації низького рівня рентабельності (прибутковості) розробки і дистрибуції лікарських препаратів від деяких захворювань [22]. Прикладом може бути лікування забутих тропічних захворювань, адже в умовах ринкової економіки фармацевтична промисловість не зацікавлена в розробці та продажу ліків, призначених для незаможних країн з тої причини, що очікуванінадходження від продажу таких лікарських засобів не покривають надзвичайно високих витрат фармацевтичних компаній. Існує ризик того, що виробники концентруватимуть свої дослідницькі зусилля на тих хворобах, які зможуть принести більший прибуток. Прикладом можуть бути так звані цивілізаційні хвороби такі як цукровий діабет, чи гіпертонія. Окрім того, виробник який витрачає значні кошти на дослідження і розробку, наражається на ризик недобросовісної конкуренції, а саме - несанкціанованого копіювання його розробок фірмами конкурентами після введення продукту на ринок до спливу терміну дії патентного захисту.

Наступна інституційна пастка, що виникає в процесі фармацевтичної діяльності спричинена асиметричністю інформації, що виявляється на кількох рівнях. По-перше, рівень знань пацієнта стосовно лікарських препаратів значно відрізняється від рівня знань медичного чи фармацевтичного працівника. Це пов'язано, передусім, із рівнем освіти, яку отримає лікар чи провізор або фармацевт. Додатковий чинник може становити різниця у доступі до інформаційних кампаній та освітних заходів (так, наприклад, йдеться про освітні заходи (тренінги) щодо рецептурних ліків, які призначені для обмеженої професійної аудиторії). Водночас, в епоху загального доступу до мережі Інтернет, покращується обізнаність пацієнтів про асортимент лікарських засобів і, навіть, про схеми лікування [26]. У випадку асиметрії володіння інформацією пацієнтом і медичним або фармацевтичним працівником існує ризик того що порада надана пацієнту лікарем чи провізором може мотивуватися бажаннямзбільшення прибутку, а не лише допомогою пацієнтові. Поряд із цим, асиметричним може бути рівень знань фармацевтичних працівників та виробників лікарські засобів. Нерозголошення інформації або ж не повна інформація про препарат може призвести до загрози життю чи здоров'ю пацієнтів або ж до нераціональних обємів споживання лікарських препаратів. Тому існує ризик використання таких ситуацій виробниками з метою отримання вищих прибутків [9].

Наступна інституційна пастка стосується ролі, яку відіграє держава у регулюванні фармацевтичного сектору. Основним актором, який найбільшою мірою визначає інституціональну логіку інституту фармації є держава, яка, зокрема, може ініціювати 
впровадження тих чи інших реформ. Як зазначалося, фармацевтичний ринок є ринком недосконалої конкуренції лікарських засобів. Обіг такого специфічного товару як лікарські препарати потребує від держави встановлення норм і правил, а також регулювання окремих процесів реєстрації, зберігання, дистрибуції, відпуску, утилізації протермінованих препаратів та ін. Завданням держави стосовно фармацевтичного сектору є захист здоров'я населення. Виконання цього завдання вимагає державного втручання з метою мінімізації проблем лікарського забезпечення. Вцілому уряд відіграє подвійну роль на фармацевтичному ринку. По-друге, держава виконує роль регулятора ринку, однак рівень ії участі залежить від обраної державної політики [11]. Істотним завданням регулювання державою фармацевтичного сектору є також формування цінової політики лікарських препаратів. У більшості розвинутих країн держава відшкодовує значну частку коштів, які населення витрачає на лікарські препарати. 3 іншого боку, уряд прагне мінімізувати витрати або обмежити темп зростання цих витрат.

Окремий різновид інституційних пасток пов'язаний із явищем конфлікту інтересів. Це явище може виникати всюди де існує конкуренція за обмежені ресурси (фармацевтичне організаційне поле в цьому сенсі не $є$ виключенням). Конфлікт інтересів стосовно проблематики цієї розвідки визначають як ситуацію, коли особа (чи інституція) підлягає подвійній лояльності - з різних підстав має певні взаємовиключні зобовязання та відстоює взаємовиключні інтереси різних акторів, дотичних до фармацевтичного сектору [18]. Перелік можливих конфліктів інтересіву організаційному полі інституту фармації досить поширений.

Одним із найбільш вичерпно описаних у західній науці конфліктів інтересів в організаційному полі фармації є конфлікти між спонсорами і науково-дослідними установами або організаціями, що проводять дослідження та апробацію нових лікарських препаратів. У Оксфордського підручнику з етики наукових досліджень знаходимо наступну інформацію: у випадку профінансованих приватними фармацевтичними компаніями експериментальних апробацій препаратів лікування раку позитивний результат зафіксовано у 95\% випадків. Водночас, коли йдеться про дослідження фінансовані державою, цей результат становить лише 62\% [23]. Очевидним є висновок, що приватні фармацевтичні компанії більшою мірою стимулюють дослідницькі колективи до оприлюднення позитивних результатів тестувань, адже негативні результати не відповідають інтересам виробника досліджуваного препарату. Відповідно, дослідник, який виконує клінічне випробування на замовлення фармацевтичної компанії може перебільшувати позитивні результати дослідження, з метою збільшення вартості акцій компанії-спонсора.

Ще одним різновидом інституційних пасток, який особливо гостро виявляється у випадку високоетатизованих (чи «державоцентричних») соціальних систем, є конфлікт інтересів між посадовими особами, відповідальними за державну політику охорони здоров'я (включаючи створення списків ліків, які надаються безкоштовно, або ж вартість яких відшкодовується) і виробниками цих лікарських засобів. Як зазначає автор книги «Нові форми корупції: соціологічний аналіз фармацевтичного сектору в Польщі», у європейських країнах найбільшим платником і клієнтом фармацевтичних компаній є держава, яка через механізми часткового або повного відшкодування вартості лікар- 
ських препаратів повинна забезпечити раціональні, прозорі та чіткі способи витрачання державних грошей [21, с. 42].

Названа інституційна пастка проявляється і у вимірі взаємодії лікарів та фармацевтичних працівників із представниками фармацевтичних компаній. Завданням лікарів є призначення лікарських препаратів виключно на основі фахових знань, а завдання представників фармацевтичних компаній полягає в тому, щоби переконати лікарів призначати або рекомендувати специфічні препарати. Представники фармацевтичних компаній прагнуть цього досягти, наприклад, через стимулювання лояльності лікаря до виробника (наприклад, спонсоруючи поїздку лікаря на зарубіжну наукову конференцію). Дещо іншу роль ніж рядові «лікарі, які виписують ліки», хоч також не без конфлікту інтересів, виконують провідні фахівці з певної галузі медицини, котрих фармацевтичні компанії називають ,лідерами громадської думки». До їхніх завдань входить, між іншими, проведення платних лекцій, що рекламують певні ліки на наукових конференціях а також і написання наукових статей в медичних журналах, зміст яких попередньо обговорюється із виробником або дистрибьютором препарату.

Та сама дилема приватно-економічного та професійно-суспільного характеру лежить в основі конфлікту інтересів між працівниками аптек, фармацевтичними компаніями та пацієнтами. Згідно з професійною етикою, кожен фармацевт, який рекомендує клієнтові аптеки певні ліки має керуватися лише благом клієнта / пацієнта. Водночас, часто буває так, що, дбаючи про прибуток аптеки, їі працівники рекомендують пацієнтам ліки, які їм, можливо, не потрібні [13]. Слід згадати про те, що провізори чи працівники аптеки часто продають ліки, які доступні без рецепту, без попереднього діагнозу, а лише визначаючи можливий стан пацієнта з його слів та зовнішнього вигляду (прикладом можуть бути пацієнти, які приходять в аптеку із скаргами на біль у животі чи головний біль і просять ліки «від болю»), в цей момент провізор пропонує певні ліки не використовуючи фахових знань і не встановлюючи етіології того чи іншого болю, що унеможливлює рекомендацію ефективного лікарського засобу.

У всіх вищезгаданих ситуаціях конфлікт інтересів може мати небажані наслідки, які можуть призвести до: деформацій знань про ефективність певних ліків; перевищення державних витрат на ті чи інші препарати (наприклад, в ситуації, коли існують дешевші аналоги); призначення пацієнтам лікарських засобів, які не є оптимальними для їхнього лікування або рекомендації провізорами ліків, які непотрібні пацієнтам.

Окреслення релевантності методологічних засад неоінституціоналізму до дослідження інституту фармації передбачає і обгрунтування конкретних «параметрів», за якими цей інститут може розглядатися уже у емпіричній площині. В цьому сенсі відповідний корпус теоретизацій є досить значним. Одним із прикладів є інструментарій, який використовується Світовою організацією здоров'я (World Health Organization Governance Toolkit). До цього інструментарію входять дві групи показників: 1) ті, що стосуються нормативного аспекту функціонування системи охорони здоров'я; 2) ті, що стосуються наслідків (чи результатів) функціонування цієї системи. До першої групи показників входить: наявність сучасної національної стратегії розвитку системи охорони здоров'я; наявність сучасної (тобто оновлюваної щопять років) політики лікарських препаратів; наявність системи державних закупівель ліків т адостатнього обсягу на- 
явних ліків; наявність національних стратегій у сфері боротьби зі СНІДом, охорони здоров’я матері і дитини, програм вакцинації; наявність і публічна доступність таких документів як бюджетна документація, щорічні показники ефективності, індикатори громадського здоров'я; наявність механізмів моніторингу оцінки системи охорони здоров'я населенням. Останній із названих елементів інструментарію оцінки якості урядування у сфері охорони здоров'я прямо стосується соціологічного супроводу цієї сфери діяльності. Таким чином, опрацювання методології відповідних соціологічних досліджень та їхнє систематичне проведення перестає бути справою виключно наукового інтересу, а стає частиною управлінських механізмів у сфері охорони здоров'я.

До другої групи показників входять ті, що стосуються наслідків (чи результатів) функціонування системи охорони здоров'я. Це: людські ресурси (наявність незаповнених вакансій, плинності кадрів та ін.); фінансування системи охорони здоров'я; система дистрибуції лікарських препаратів; наявність та частка неформального обігу коштів в системі охорони здоров'я; фармацевтична регуляція (зокрема, відсоток підроблених ліків на ринку); наявність ефективних організацій, які представляють громадянське суспільство і мають механізми впливу на державну політику в сфері охорони здоров'я (зокрема, через систему громадських слухань, петицій, участі в розробці законопроектів та ін.).

Інший підхід до окреслення індикаторів функціонування системи охорони здоров’я запропонований М. Ісламом (M. Islam), який пропонує використовувати наступний перелік із пяти індикаторів: доступ до інформації (тут йдеться про інформацію, доступні широкому колу причетних і зацікавлених сторін (англ. - stakeholders), що стосується трендів розвитку системи охорони здоров'я та релевантних управлінських заходів; формування та планування управлінських заходів (йдеться про наявність обговорень, втілення та моніторингу виконання управлінських рішень у сфері охорони здоров'я); соціальна участь та респонсивність ( йдеться про залучення широкого кола причетних і зацікавлених сторін (наурядові організації, пацієнтські організації) до процесу планування, формування бюджету та моніторингу функціонування системи охорони здоров'я); підзвітність (публічна доступність документації, що стосується статистичних показників стану здоров'я населення, фінансування системи охорони здоров'я, наявність організацій, які контролюють зловживання у цій сфері та захищають інтереси пацієнтів); регуляція (наявність відповідних органів, які регулюють питання безпеки, ефективності, якості медичних послуг та лікарських препаратів). Для змістовного висвітлення вказаних аспектів М. Іслам запропонував 40 показників у формі питань для напівструктурованого інтервю. Цінність вказаного інструментарію полягає, зокрема, в тому, що останній був опрацьований автором саме для країн із низьким рівнем добробуту (англ. - low-income countries) [16].

Б. Хенсл зі співавторами запропонували систему індикаторів для евалюації управління системою охорони здоров'я, яка має страховий характер [14]. Ї̈̈ складовими є: система прийняття рішень, участь зацікавлених сторін, прозорість та доступ до інформації, контроль і регуляція, стабільність. Автори здійснили низку досліджень у країнах, які нещодавно запозичли страхову модель медицини. Серед цих кейсів особливий інтерес викликає Естонія, країна, яка має невеликий досвід функціонування 
страхової моделі медицини і, поряд з цим, до недавнього часу мала систему охорони здоров'я, наближену до української.

М. Льюіс та Дж. Петерсон пропонують наступні пять індикаторів за якими має відбуватися евалюація функціонування системи охорони здоров'я: формування бюджету та управління іншими ресурсами, із особливою увагою до неефективного розподілу;

2) питання ефективності надання медичних послуг із фокусом на індивідуальному рівні виконання професійних обовязків працівниками системи охорони здоров'я; 3) функціонування медичних інституцій, зокрема у вимірі середньої тривалості амбулаторного лікування, відсотку поширення інфекцій у медичних закладах, рівня задоволеності пацієнтів; 4) неформальні виплати, які здійснюють пацієнти, для того, щоби отримати доступ до гарантованих державою медичних послуг; 5) сприйняття рівня корупції у системі охорони здоров'я з боку експертів та пацієнтів [19].

Розмежовують три комплексних індикатори функціонування системи охорони здоров'я: структурні, процесуальні та індикатор наслідків. Структурні індикатори стосуються наявності чи відсутності правових та адміністративних норм (таких, наприклад, перелік Національний перелік основних лікарських засобів). Процесуальні індикатори стосуються того, наскільки ефективно функціонують окремі інституції у системі охорони здоров'я та втілюються окремі програми (такі, наприклад, як реімбурсація за програмою «Доступні ліки»). Індикатори наслідків стосуються статистичних показників стану громадського здоров'я, а також експертної та масової оцінки ефективності їі функціонування.

Представлений огляд ймовірних перспективних напрямків соціологічної ева люації фармацевтичної діяльності потребує систематизації і у цьому, видається, доречним застосування типологію проблем урядування у фармацевтичному секторі, яку запропонували Дж. Цайлус (J. Cylus), O. Воутерс (O. Wouters) та П. Канавос (P. Kanavos) у спільній статті «Зрозуміти роль урядування у фармацевтичному секторі: від лабораторії до пацієнта». Автори виділяють пять елементів урядування в фармацевтичному секторі. Це: підзвітність (відповідальність), прозорість, участь зацікавлених сторін, послідовність та відсутність зловживань, ефективність урядування. Проблеми урядування у фармацевтичному секторі виникають, зазвичай, унаслідок суперечностей поміж вимогами права та загальносуспільними інтересами, з одного боку, та логікою максимізації прибутків і мінімізації витрат, якої дотримуються комерційні структури, учасники фармацевтичної діяльності, з іншого боку. Автори наголошують, що такого роду проблеми урядування частіше за все виникають у країнах із низьким рівнем добробуту та слабкою (нерозвинутою) системою урядування у фармацевтичному секторі.

Почергово розглянемо можливі проблемні аспекти урядування в фармацевтичному секторі, а також відповідні можливості соціологічної евалюації. Першим етапом на якому наголошують автори є Введення лікарського препарату на ринок. На цьому етапі можуть виникнути проблеми урядування, повязані із підзвітністю (відповідальністю) та із послідовністю та відсутністю зловживань. Саме на цьому етапі, зокрема, приймаються рішення щодо безпечності препаратів, їхньої ефективності та якості, приймаються рішення про реімбурсацію. У країнах зі слабкою системою державного 
регулювання (переважно, відносно бідні країни) на цьому етапі виникають проблеми із якістю медичних препаратів. Так, згідно з даними Інтерполу, близько $30 \%$ відсотків лікарських препаратів у таких країнах є підробними, а у деяких африканських країнах цей показник може наближатися до 50 \% [10]. Щорічно Інтерполом проводяться операції по боротьбі з продажем заборонених і підроблених фармацевтичних препаратів через Інтернет. У 2015 році у межах операції Pangea VIII правоохоронцям вдялося вилучити підроблених і заборонених лікарських засобів на суму понад 80 мільйонів доларів [15].

Проблеми урядування в фармацевтичному секторі

Таблиия 1

(за Дж. Цайлус, О. Воутерс та П. Канавос) [12, с. 177]

\begin{tabular}{|c|c|c|c|c|c|}
\hline $\begin{array}{l}\text { Етапи шляху } \\
\text { лікарських } \\
\text { препаратів від } \\
\text { виробника до споживача }\end{array}$ & 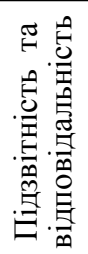 & $\begin{array}{l}\hat{b} \\
\stackrel{0}{0} \\
\tilde{0} \\
\tilde{0} \\
\stackrel{0}{0}\end{array}$ & 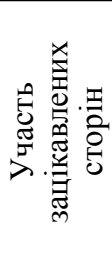 & 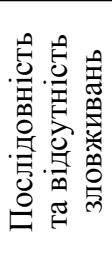 & 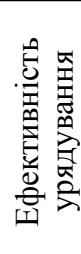 \\
\hline Введення препарату на ринок & & & & & \\
\hline Встановлення цін & & & & & \\
\hline Розподіл ризиків & & & & & \\
\hline Ланюг дистрибції & & & & & \\
\hline
\end{tabular}

Наступним кроком на шляху лікарського засобу від виробника до споживача $є$ встановлення ціни на нього. Найбільш поширеною практикою встановлення цін у європейських країнах є референтне ціноутворення (англ. - External price referencing). Відповідно до цієї управлінської практики національні ціни на лікарські препарати утворюються через співставлення із відповідними цінами у низці референтних (як правило, сусідніх) країн. Механізми референтного ціноутворення різняться у різних країнах: різняться правові норми; конкретна методологія ціноутворення (наприклад, встановлення мінімальної чи середньої зафіксованої у сусідніх країнах ціни); частота перегляду цін у сусідніх (референтних) країнах; правила апеляції щодо встановленої державним регулятором ціни; логістичні та ситуативні чинники (наприклад, коливання національної валюти та ін.).

У процесі референтного ціноутворення можуть виникати істотні виклики та проблеми. Так, можливими і часто фіксованими є випадки маніпуляції цінами із боку виробників препаратів. Такі дії можуть не кваліфікуватися правом як протизаконні та карані, але, тим не менше, чинять негативний вплив на громадське здоров'я та державні фінанси. Основою для таких недобросовісних дій $є$ те, що за референтної чсистеми ціноутвоерння, зміни ціни у одних країнах тягнуть за собою їхні зміни у інших. Відповідно, виробники препаратів можуть спочатку запроваджувати нові препарати у багат- 
ших країнах, які більш ймовірно, погодяться на високу ціну, і лише пізніше виводити ці препарати на ринки інших (бідніших) країн. Таким чином, часовий менеджмент впровадження препаратів на національні ринки дає можливість виробникам препаратів маніпулювати системою референтного ціноутворення. Іншим способом маніпулювання системою референтного ціноутворення є надання непрозорих (конфіденційних) знижок, які не фіксуються державними регуляторами фармацевтичної діяльності. Управління ціноутворенням на лікарські препарати може бути справжнім викликом для відповідних управлінських органів. Це пояснюється, крім згааних вище аспектів, і тим, що лікарські препарати у різних країнах можуть мати різні імена, можуть бути по-різному розфасовані та мати різне дозування та ін. Якщо ціни переглядати часто - для цього необхідні значні людські та фінансові ресурси. Питанням є оптимальний штат спеціалізованої служби, що мала б займатися ціноутворенням. Як повідомляють Канавос та ін., у Чехії о складу відповідної служби входять 65 осіб, а у Греції лише кілька осіб. Зокрема, в цьому аспекті виникає необхідність проведення відповідних досліджень, ймовірно, на підставі використання експертних інтервю.

Черговий проблемний аспект урядування в фармацевтичному секторі, який повинен бути обєктом соціологічної евалюації є так звані рішення із уникнення ризиків (англ. - risk-sharing agreements). Йдеться про схильність виробників лікарських препаратів вести переговори із державними регулятивними інституціями у конфіденційний спосіб, який виключає участь громадськості і, зокрема, участь пацієнтських організацій. Зокрема, виробники лікарських препаратів можуть йти на зниження ціни на препарат, за умови, якщо державні регулятивні інституції не будуть включати цей препарат у перелік референтних у процесі ціноутворення в інших країнах. Така ситуація може мати наслідком як невключення певних препаратів у перелік тих, на які поширюється реімбурсація так і встановлення на препарати ціни, яка не цілком влаштовує споживачів. Подібно ж, конфіденційний спосіб переговорів поміж виробниками та фармацевтами, які займаються дистрибуцією може спричиняти ризик у тому, сенсі, що простимульовані виробниками (наприклад, через систему конфіденційних знижок) фармацевти можуть радити покупцям ті чи інші препарати, що призводить ло неоптимального вибору.

Врешті, важливим аспектом функціонцування системи охорони здоров'я є дистрибуція лікарських препаратів. Своєрідна інституційна пастка може виникати за умови великої різниці поміж вартістю лікарького препарату і часткою ціни, яка відшкодовується реімбурсацією. За таких умов виробники та постачальники охочіше виводять на ринок препарати, у яких така різниця є невисокою, а фармацевти більш охоче пропонують споживачам ті ж таки ліки, ціну яких значною мірою покриває реімбурсація [17].

Підсумуємо результати цієї розвідки. Інститут фармації становить собою складний комплекс, спрямований на виконання важливою функції - функції збереження та покращення здоров'я населення, що реалізується через надання кваліфікованої фармацевтичної допомоги [7]. Фактично сучасна фармація перетворилась у відносно автономну інституційну сферу зі складною багаторівневою структурою, який, зокрема, характеризується: створенням великих науково-дослідних установ із розробки та апробації лікарських препаратів; створенням системи підготовки фармацевтичних кадрів у високоспеціалізованих навчальних закладах; розвитком великих фармацев- 
тичних фірм та компаній; виникненням фармацевтичного ринку з усіма ринковими механізмами; його високою концентрацією; створенням потужних рекламних та маркетингових служб, які стимулюють споживання лікарських препаратів; створенням правових норм, що регулюють фармацевтичну діяльність. Відповідно до теоретикометодологічних засад неоінституціоналізму сформулюємо авторське розуміненя фармації як організаційного поля: це складна, багаторівнева система, яка включає розробників, виробників, дистрибьюторів лікарських засобів, алгоритми їх постачання та відпуску, надавачів фармацевтичних послуг, їхніх споживачів та публічні інституції (державного і недержавного характеру), обєднаних спільною інституціональною логікою та системами управління».

Таким чином, вважаємо, що інститут фармації може досліджуватися так само як кожен інший соціальний інститут чи його елемент, тобто з перспективи системи ролей, які базуються на уявленнях та нормах, структурах, функціях, сталих моделях поведінки. Фармацевтичний сектор може досліджуватися з перспективи відповідей на виклики сучасних суспільств (наприклад: на зміну моделі взаємодії користувача, споживача лікарських препаратів та фармацевтичного працівника, що підвищує необхідність розвитку комунікативних навичок фармацевтичних кадрів; на вкорінені дисфункційні моделі поведінки корситувачів і споживачів лікарських препаратів, зокрема, узалежнення від лікарських препаратів та самолікування; на недобросовісну діяльність виробників лікарських препаратів, які стимулюють неоптимальний вибір або споживання препаратів та ін.

\section{СПИСОК ВИКОРИСТАНОї ЛІТЕРАТУРИ}

1. Бондарева И. В. Сравнительный анализ методов оценки приспособления украинских фармацевтических предприятий к изменениям внешней среды / И. В. Бондарева, И. В. Пестун, 3. Б. Сакипова // Фармацевтический журнал. - 2014. - 4. - С. 4-8.

2. Гетьман М. А. Клиентоориентированная концепция контроля процессов оказания медицинской помощи в России / М. А. Гетьман // Московские аптеки. $-2006 .-$ № 9 (153). - C. 25-30.

3. Головаха Е. И. Законы институциональных изменений / Е. И. Головаха // Вісник Харківського національного університету імені В. Н. Каразіна. Серія «Соціологічні дослідження сучасного суспільства: методологія, теорія, методи». - 2011. - № 948. Вип. 28. - С. 9-14.

4. Дадус H. Н. Социальный статус и престиж фармацевтического работника в современном обществе / С. В. Кононова, Е. В. Шаленкова, С. В. Петрова, Л. С. Богомолова // Фармация. - 2011. - № 1 (14). - С. 15-20.

5. Полтерович В. М. Институциональные ловушки: есть ли выход? // Общественные науки и современность. -2004 . - № 3. - С. 5-16.

6. Скотт P. Конкурирующие логики в здравоохранении: профессиональная, государственная и менеджериальная / Р. Скотт // Экономическая социология. - 2007. - Т. 8, No 1. - C. $27-45$.

7. Ткаченко Н. О. Теоретико-методологічні аспекти форму- вання комунітарної соціальної відповідальності у фармації / Н. О. Ткаченко, Л. М. Унгурян, Б. П. Громовик // Одеський медичний журнал. - 2014. - № 5. - С. 34-38. 
8. Щудло C. А. Вища освіта у пошуку якості : quo vadis: монографія / Світлана Щудло. Харків - Дрогобич : Коло, 2012. - 340 с.

9. Bennett $S$. Public-private roles in the pharmaceutical sector implications for equitable access and rational drug use / S. Bennett, J. Quick, G.Velasquez // DAP Series no. 5, WHO/ DAP/97.12, World Health Organization, Action Programme on Essential Drug. 1997 [Available at: http://archives.who.int/tbs/global/whozip27e.pdf [доступ: 20.09.2017].

10. Cockburn $R$. The global threat of counterfeit drugs: why industry and governments must communicate the dangers / P. N. Newton, E. K. Agyarko, D. Akunyili, N. J. White // PLoS Medicine, 2005, Vol. 2(4). e100. doi:10.1371/journal.pmed.0020100

11. Corstjens M. Marketing Strategy in the Pharmaceutical Industry, 1991. Chapman \& Hall, London.

12. Cylus $J$. Understanding the role of governance in the pharmaceutical sector: from laboratory to patient / J. Cylus, O. Wouters, P. Kanavos. In Strengthening Health System Governance Better policies, stronger performance. Ed by Scott L. Greer, Matthias Wismar and Josep Figueras. Open University Press. McGraw-Hill Education. 2016. Pp. 173-187.

13. Grychtoł A. Dylematy moralne polskich aptekarzy / A. Grychtoł // Annales. Etyka w życiu gospodarczym. 2015, vol. 18, nr 1. [Available at: http://www.annalesonline.uni.lodz.pl/archiwum/2015/2015_1_grychtol_103_113.pdf 20.09.2017]

14. Hansl B. Good governance dimensions in mandatory health insurance: a framework for performance assessment / B. Hansl, A. Rahola, P. Gottret, A. Leive // W. D. Savedoff and P. Gottret (eds) Governing Mandatory Health Insurance: Learning from Experience. 2008. Washington, DC: World Bank.

15. Interpol operatons. [Available at:https://www.interpol.int/Crime-areas/Pharmaceuticalcrime/Operations/Operation-Pangea. 20.09.2017]

16. Islam M. Health Systems Assessment Approach: A How-To Manual. Submitted to USAID in collaboration with Health Systems 20/20 / M. Islam// Partners for Health Reform, Quality Assurance Project, and Rational Pharmaceutical Management, Arlington, 2008. VA: Management Sciences for Health.

17. Kanavos $P$. Pharmacy discounts on generic medicines in France: is there room for further effi ciency savings? / D. Taylor, P. Kanavos // Current Medical Research and Opinion, 2007. 23(10): Pp. 2467-76.

18. Lewicka-Strzałecka A. Konfl ikt interesów / A. Lewicka-Strzałecka // Etyka, biznes, odpowiedzialność, red. W. Gasparski, WN PWN, Warszawa 2012, s. 249.

19. Lewis M. Governance in Health Care Delivery: Raising Performance.Washington / M. Lewis, G. Pettersson // DC: World Bank. 2009.

20. Matchar D. B. Evidence-based guidelines for migraine headache / Matchar D. B., Young W. B., Rosenberg J. H. et al. // Neurology. 2000. Vol. 55: P. 754-762.

21. Polak P. Nowe formy korupcji / P. Polak // Analiza socjologiczna sektora farmaceutycznego w Polsce, Nomos, Kraków, 2011.

22. Rawlins M. Cutting the cost of drug development?, Nature Reviews Drug Discovery, 2004. No. 3, s. 360-364.

23. Resnik D. B. Responsible Conduct of Research / D. B. Resnik, E. Shamoo // 2nd Ed., Oxford University Press 2009, s. 190.

24. Scott $R$. Conceptualizing Organizational Fields: Linking Organizations and Societal Systems / R. Scott // Systemrationalitat und Partialinteresse. Ed. by H. Derlien, U. Gerhardt, F. Scharpf. Baden-Baden: Nomos Verlagsgesellschaft, 1994. - P. 207-208.

25. Scott R. Institutions and Organizations / R. Scott // $2^{\text {nd }}$ ed. Thousand Oaks, CA: Sage Publications. 2001: 48.

26. Tufts Managed Care Institute, 2001, Patient Education and the Internet, Boston, [Available at: http://www.thci.org/downloads/ttopic91001.pdf. 10.09.2017]. 


\section{REFERENCES}

1. Bondareva I. V. Sravnitelnyj analiz metodov ocenki prisposobleniya ukrainskih farmacevticheskih predpriyatij $k$ izmeneniyam vneshnej sredy [Comparative analysis of methods for assessing the adaptation of Ukrainian pharmaceutical enterprises to changes in the external environment ] Farmacevticheskij zhurnal 4, 2014. - P. 4-8. [in Russian]

2. Getman M. A. Klientoorientirovanaya koncepcyya kontrolya processov okazaniya medicynskoj pomoshchi $v$ Rosii [The client-oriented concept of monitoring the processes of rendering medical care in Russia ] Moskovskije apteki. - 2006, № 9 (153). - P. 25-30. [in Russian]

3. Golovakh Je. I. Zakony institucyonalnyh izmenenij [Laws of Institutional Change] Visnyk Harkivskogo nacionalnogo universytetu imeni V. N. Karazina. Seriya «Sociologichni doslidzennya suchasnogo suspilstv: metodologiya, teoriya, metody». - 2011. - № 948. Vyp. 28. - P. 9-14. [in Ukrainian]

4. Dadus N. N. Socyalnyj status I prestizh farmacevticheskogo rabotnika v sovremennom obshchestve [The social status and prestige of a pharmaceutical worker in modern society] Farmacyya. - 2011. - №1(14). - P. 15-20. [in Russian]

5. Polterovych V. M. Institucyonalnyje lovushki: jest li vyhod? [Institutional traps: is there a way out?] Obshchestvennyje nauki i sovremennost. 2004. № 3. - P. 5-16.

6. 35. Skot R. Konkurirujushchije logiki v zdravoohraneniji: professionalnaya, gosudarstvennaya I menedzerialnaya [Competing logic in health care: professional, state and managerial] Ekonomicheskaya socyologiya. 2007. Vol. 8., No1. - P. 27-45.

7. Tkachenko N. O. Teoretiko-metodologichni aspekty formuvannya komunitarnoji socialnoji vidpovidalnosti u farmaciji [Teoretiko-metodologicheskii Aspect form-vannya komunitarno sotsialnogo vidpovidantnosti u pharmacies] Odeskyj medychnyk zhurnal. - 2014. - №5. - P. 34-38.

8. Shchudlo $S$. A. Vyshcha osvita u poshuku yakosti [Higher education in quality search]. Drogobych: Kolo, 2012. - 340 p.

9. Bennett S., J. Quick, G.Velasquez Public-private roles in the pharmaceutical sector implications for equitable access and rational drug use. DAP Series no. 5, WHO/DAP/97.12, World Health Organization, Action Programme on Essential Drug. 1997 [Available at: http://archives.who.int/tbs/global/whozip27e.pdf 20.09.2017].

10. Cockburn R., P. N. Newton, E. K. Agyarko, D. Akunyili, N. J. White The global threat of counterfeit drugs: why industry and governments must communicate the dangers. PLoS Medicine, 2005, Vol. 2(4). e100. doi:10.1371/journal.pmed.0020100.

11. Corstjens M. Marketing Strategy in the Pharmaceutical Industry, 1991. Chapman \& Hall, London.

12. Cylus J. O. Wouters, P. Kanavos. Understanding the role of governance in the pharmaceutical sector: from laboratory to patient. In Strengthening Health System Governance Better policies, stronger performance. Ed by Scott L. Greer, Matthias Wismar and Josep Figueras. Open University Press. McGraw-Hill Education. 2016. P. 173-187.

13. Grychtot A. Dylematy moralne polskich aptekarzy. Annales. Etyka w życiu gospodarczym. 2015, vol. 18, $\mathrm{nr}$ 1. [Available at: http://www.annalesonline.uni.lodz.pl/archiwum/2015/2015 1 grychtol 103 113.pdf 20.09.2017]

14. Hansl B., A. Rahola, P. Gottret, A. Leive. Good governance dimensions in mandatory health insurance: a framework for performance assessment. In B. Hansl, W. D. Savedoff and P. Gottret (eds) Governing Mandatory Health Insurance: Learning from Experience. 2008. Washington, DC: World Bank.

15. Interpol operatons. [Available at: https://www.interpol.int/Crime-areas/Pharmaceuticalcrime/Operations/Operation-Pangea. 20.09.2017] 
16. Islam M. Health Systems Assessment Approach: A How-To Manual. Submitted to USAID in collaboration with Health Systems 20/20. Partners for Health Reform, Quality Assurance Project, and Rational Pharmaceutical Management, Arlington, 2008. VA: Management Sciences for Health.

17. Kanavos P., D. Taylor, Pharmacy discounts on generic medicines in France: is there room for further effi ciency savings? Current Medical Research and Opinion, 2007. 23(10): P. 2467-76.

18. Lewicka-Strzałecka A. Konfl ikt interesów. Etyka, biznes, odpowiedzialność, red. W. Gasparski, WN PWN, Warszawa 2012, s. 249.

19. Lewis M., G. Pettersson Governance in Health Care Delivery: Raising Performance. Washington. DC: World Bank. 2009.

20. Matchar D. B. Young W. B., Rosenberg J. H. et al. Evidence-based guidelines for migraine headache. Neurology. 2000. Vol. 55: P. 754-762.

21. Polak $P$. Nowe formy korupcji. Analiza socjologiczna sektora farmaceutycznego w Polsce, Nomos, Kraków, 2011.

22. Rawlins M. Cutting the cost of drug development? Nature Reviews Drug Discovery, 2004. No. 3, s. 360-364.

23. Resnik D. B. E. Shamoo Responsible Conduct of Research. 2nd Ed., Oxford University Press 2009, s. 190.

24. Scott R. Conceptualizing Organizational Fields: Linking Organizations and Societal Systems. Systemrationalitat und Partialinteresse. Ed. by H. Derlien, U. Gerhardt, F. Scharpf. Baden-Baden: Nomos Verlagsgesellschaft, 1994. - Pp. 207-208.

25. Scott $R$. Institutions and Organizations. 2al ed. Thousand Oaks, CA: Sage Publications. 2001: 48 .

26. Tufts Managed Care Institute, 2001, Patient Education and the Internet, Boston, [Available at: http://www.thci.org/downloads/ttopic91001.pdf. 10.09.2017].

\title{
NEO-INSTITUTIONALISM AS A THEORETICAL AND METHODOLOGICAL BASIS FOR THE SOCIOLOGICAL RESEARCH OF PHARMACY
}

\author{
S. G. Kniazkov \\ National Pedagogical University named after MP Drahomanov \\ Kiev, Ukraine \\ knyazkov_s_g@ukr.net
}

In the context of the institutional reforms that are ongoing in Ukrainian society, one of the most controversial and at the same time necessary is the reform of the health care institution. The need for a radical revision of the principles of the functioning of this institution is combined with numerous risks, which actualizes the problem of sociological evaluation of measures to reform the health care institution in general and its component. The neoliberal vector of reforms envisages, among other measures for optimizing public administration and public expenditures, a gradual transition to a model of insurance medicine. The threats 
associated with the introduction of insurance medicine, in particular, in pharmaceutical activities, require sociological monitoring of social situations, needs and concerns of key agents involved in the problem situation: professional pharmacists, drug users, pharmaceutical manufacturers, and pharmaceutical industry representatives. The problem of sociological support of pharmaceutical activity, and its sociological evaluation, in particular, covers a range of issues such as: an assessment of the effectiveness of measures to reform pharmaceutical sector by various groups of involved agents; vision of the risks of transition to the insurance system of medicine and pharmaceutical activities, in particular; degree of satisfaction of drug users.

It should be noted that in the process of pharmaceutical activity there are contradictions of ethical, fi nancial and professional motives. Due to competition in the pharmaceutical market, its further commercialization is compounded by the fi nancial and economic, not the medical and social component of pharmaceutical activity, which exacerbates the moral risks associated with this area of activity. The risk of unscrupulous behavior by pharmacists and even drug manufacturers is increasing; the problem of self-treatment, the presence of counterfeit medicines on the market, asymmetric information on medicinal products and their non-optimal consumer choice remains an acute problem. This, in turn, actualizes the sociological perspective on evaluation of pharmaceutical sector functioning.

Key words: neo-institutionalism, pharmacy, evaluation. 